\title{
Projektarbejde og akademisk IT-skoling
}

\section{Simon Heilesen}

\section{Lektor}

Simon Heilesen er lektor ved Institut for Mennesker og Teknologi, Roskilde Universitet. Han er knyttet til Enheden for Akademisk Efteruddannelse (EAE), hvor han arbejder med Akademisk IT, dvs. forskning, formidling og undervisning med inddragelse af digitale medier. Aktuelt arbejder han med læringsrum (fysiske og virtuelle), med digital dannelse, og med udvikling af ældres ITfærdigheder.

\section{Søren Davidsen}

Informationsspecialist

Søren Davidsen er cand.mag. og

cand.scient.bibl. og har siden 2014 arbejdet som fagreferent og informationsspecialist ved Roskilde Universitetsbibliotek. Her arbejder han med undervisning og med evaluering af bibliotekets services. Før sin nuværende ansættelse har han arbejdet i

folkebibliotekssektoren.
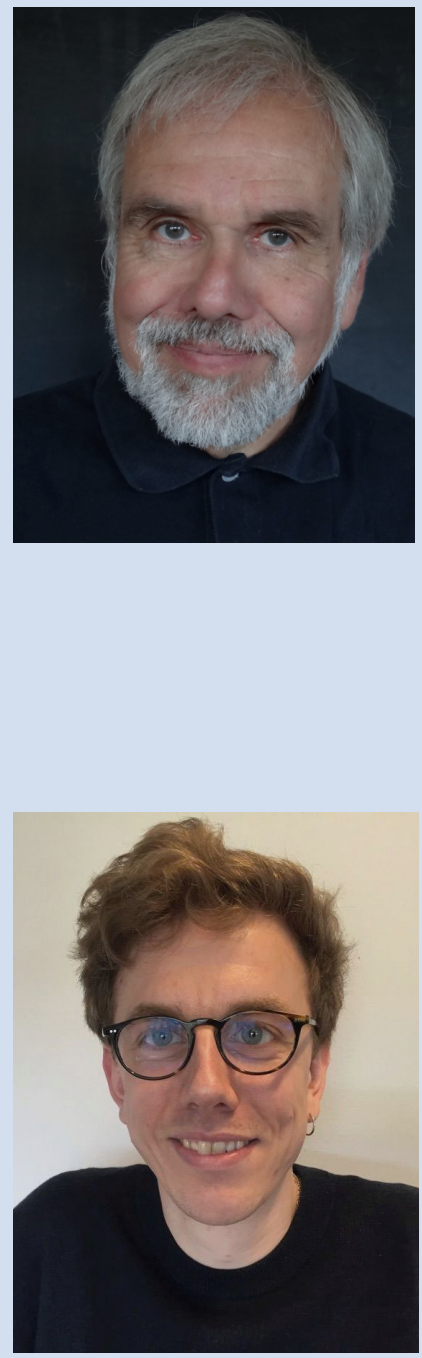


\section{Resumé}

Artiklen redegør for en kortlægning foretaget i 2015 af de studerendes brug af IT-værktøjer i forbindelse med projektarbejde på Roskilde Universitet. På grundlag af en spørgeskemaundersøgelse samt interviews med tolv studerende forklares anvendelsen af IT-værktøjer i projektarbejdets forskellige faser. Som ramme for undersøgelsen diskuteres begrebet "akademisk digital skoling", og der trækkes linjer til internationale undersøgelser, som synes at bekræfte, at studerende reelt bruger et fătal af IT-værktøjer, og at disse i hovedsagen ikke er udviklet til akademiske formål. Undersøgelsens resultater sammenholdes med det udvalg af IT-værktøjer, universitetet stiller til rådighed for ansatte og studerende. Afslutningsvis diskuteres de mulige årsager til tingenes tilstand, samt hvordan det vil være muligt at hæve niveauet af den akademiske digitale skoling.

\section{Indledning}

Problemorienteret projektarbejde er et særkende ved Roskilde Universitet (RUC). For nylig er der udgivet en antologi om emnet, og under arbejdet med den er to forhold blevet tydelige for bogens forfattere (Andersen \& Heilesen, 2015). For det første kan der ikke gives en entydig beskrivelse af, hvad problemorienteret projektarbejde er. For det andet ved RUC's undervisere meget lidt om, hvordan de studerende tilrettelægger og udfører projektarbejdet. Dette gælder ikke mindst de studerendes anvendelse af digitale medier. Det har derfor været en naturlig fortsættelse af bogprojektet at forsøge at kortlægge de studerendes IT-anvendelse i en akademisk sammenhæng.

Denne kortlægning, som er emnet for artiklen, blev udført fra maj til oktober 2015 og omfattede dels en spørgeskemaundersøgelse, dels en række opfølgende interviews med studerende. Hovedkonklusionen på undersøgelsen er, at de studerende anvender et ret begrænset udvalg af ITværktøjer, og at disse kun i beskedent omfang omfatter de mange ressourcer og værktøjer, som universitetet frit stiller til rådighed.

I det følgende vil vi først etablere en ramme for undersøgelsen ved at diskutere nogle centrale begreber samt se på eksisterende forskning på området. Dernæst vil vi gøre rede for undersøgelsen og de resultater, der er kommet ud af den. Endelig vil vi diskutere, hvad konsekvenserne er af det billede, vi tegner, samt pege på nogle muligheder for at skabe forandring.

\section{Digitalt indfødte og akademisk skoling}

Dagens studerende er vokset op med digitale medier, ikke mindst internettet, og det har i en årrække været en fremherskende antagelse, at denne nye "Generation Y", "Millenials", "Digital natives", mm. (GallardoEchenique, 2015, 160 ff.) derfor har udviklet en række særlige vaner og egenskaber i omgangen med digitale teknologier (Gallardo-Echenique, 
2015, p. 166; Lai \& Hong, 2015, p. 727). Blandt disse er angiveligt evnen til intuitivt og let at forstå og anvende digitale medier.

Denne ikke altid særligt klart udtalte tro på at de studerende ikke blot er itmæssigt selvkørende, men også er innovatorer, har blandt andet været lagt til grund for en forventning på Roskilde Universitet om, at

"De studerende kan således spille en væsentlig rolle, hvis man ikke blot inddrager dem i eksisterende initiativer, men også opfordrer dem til at anvise og afprøve innovative anvendelser af nye medier både i forbindelse med den skemalagte undervisning og projektarbejdet". (Andersen \& Heilesen, 2013, p. 149)

At mange unge bruger lang tid på digitale medier er næppe til diskussion. Det er derimod påstanden om, at de dermed også er særligt teknologikyndige såvel generelt, som når det gælder bestemte faglige anvendelser af digitale medier. En række studier har påpeget, at der mangler empirisk grundlag for påstanden, og at der nærmere er tale om, at mange unge mestrer et begrænset repertoire af digitale værktøjer, samt at generationsbegrebet er løst defineret og helt overser potentielt væsentlige sociale og kulturelle faktorer (Gallardo-Echenique, 2015; Lai \& Hong, 2015; Smith, 2012).

Særligt relevant i den aktuelle sammenhæng er konklusionen i to nyligt udgivne, omfattende litteratur reviews, nemlig at de digitalt indfødte hverken anvender særligt mange eller særligt avancerede IT-værktøjer, og at de heller ikke synes at bruge dem til bevidst at udvikle nye akademiske praksisser:

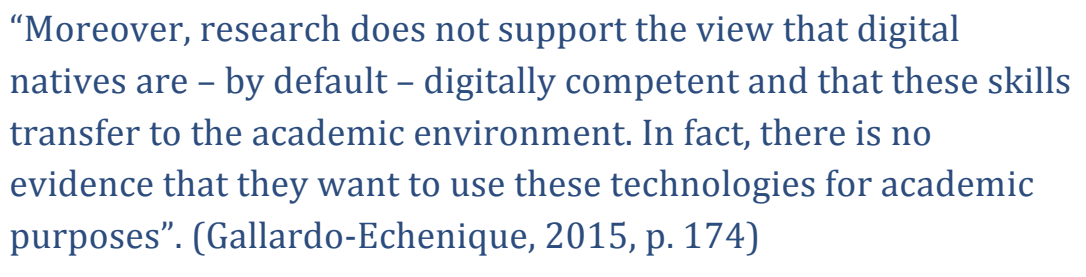

Ydermere er der ikke belæg for at hævde, at disse teknologier bliver brugt i en læringsmæssig sammenhæng:

"This study therefore supported findings from previous studies that although the net generation students use new digital technologies in their everyday life, they do not use them extensively for learning purposes ..., and no major differences in technology use between generations were found. (Lai \& Hong, 2015, p. 735)

Endelig er antallet af anvendte teknologier som sagt ret lavt: 
In this study, the digital technology tools used by students for university and social/personal activities were rather limited.... Significant generational differences detected for the use of some of the six most commonly used digital tools for university work and social/personal activities were not practically meaningful, similar to those found in previous studies. For example, Thompson (2013) found that although the assumption that the net generation is universally proficient with a variety of digital technology tools, students might actually use a limited range of digital tools". (Lai \& Hong, 2015, p. 735)

Over for de digitalt indfødte står de digitale indvandrere, altså alle dem, som ikke voksede op med en computer på børneværelset og med personlige IT-værktøjer til rådighed under uddannelsen. Udtrykket "indvandrer" er lige så meningsløst generaliserende som "indfødt". Blandt ansatte på videregående uddannelser er der den dag i dag, på tværs af bl.a. aldersskel og fag, højt besungne ildsjæle såvel som fodslæbere. På undervisningsområdet er visse IT-værktøjer, især e-læringsplatforme (LMS), meget anvendt. Men de meget store forventninger til, hvordan IT kan revolutionere vilkårene for forskning, synes endnu ikke at være indfriet - i det mindste ikke i USA:

"Yet the foundation of academic life-the scholarship on which everything else is built-remains surprisingly unaltered. The articles and books that scholars produce today bear little mark of the digital age in which they are created. Researchers routinely use electronic tools in their professional lives but not to transform the substance or form of their scholarship. (Ayers, 2013, p.27)

Dette ser ikke ud til at ændre sig lige foreløbig:

"Not many scholars worry about this situation. A recent random
sample by Ithaka S+R finds that two-thirds of faculty-across the
sciences, social sciences, and humanities—judge that new digital
methods are "not valuable or important" for their research. The
study notes that even though "digital practices may influence
these scholars' work in a variety of ways," few scholars see "the
value of integrating digital practices into their work as a
deliberate activity." Many scholars judge that using digital
methods would simply "not be worth the time"; about one-third
of the respondents said they do not know "how to effectively
integrate digital research activities and methodologies" into their
work and have no desire to learn". (Ayers, 2013, p.27)


En nyere dansk undersøgelse af en gruppe universitetsforskeres informationsadfærd ligger i tråd med de amerikanske iagttagelser og viser, at inddragelse af nye medier ikke forekommer forskerne at være besværet værd (Fisker, Korsgaard \& Hansen, 2014).

\section{Akademisk skoling og teknologien}

I den aktuelle sammenhæng har vi valgt at benytte begrebet skoling frem for "dannelse", fordi "dannelse" (Bildung) har en bred kulturel betydning, som rækker videre end de forhold, vi undersøger. Med skoling menes her en metodisk, faglig uddannelse, som ud over tilegnet viden også sætter den enkelte i stand til at arbejde selvstændigt, metodisk og systematisk med en faglig problemstilling. Som akademisk uddannet er man professionel inden for et fagområde. Man behersker fagets værktøjer og metoder, og man arbejder inden for en veldefineret teoretisk forståelsesramme.

Med "akademisk digital skoling" henviser vi til de kompetencer, en studerende i dag skal beherske for med kvalificeret udnyttelse af digitale værktøjer effektivt og metodisk at kunne tilegne sig, bearbejde og formidle viden. Som al anden skoling kan den naturligvis gradbøjes, men vi fokuserer i denne undersøgelse på de grundlæggende færdigheder snarere end de sofistikerede; på det generelle, det almene, snarere end det højt specialiserede. Endvidere vil vi anskue begrebet ud fra en praktisk, instrumentel synsvinkel, nemlig alene de værktøjer som er en praktisk og nødvendig forudsætning for at kunne arbejde professionelt på en tidssvarende måde.

Skolingen udgør en del af fundamentet for digital dannelse (digital literacy; Littlejohn, Beetham \& McGill, 2012) og indgår i beslægtede begreber som "digital scholarship" (Ayers, 2013; Thanos, 2014) og "e-science" (i Danmark med en særligt bred betydning, se f.eks. vidensportal.deic.dk/node/7).

Uden at ville deltage i diskussionen om, hvad digital dannelse er, vil vi med Spenglers definition af begrebet illustrere de kompetencekrav, som indgår i dannelsen (Spengler, 2015, p 14ff.). Spengler skelner mellem tre beslægtede former for kompetence: Computer literacy (forståelse af begreber og terminologi forbundet med computere, samt hensigtsmæssig betjening af disse), Information literacy (beherskelsen af værktøjer til at søge, analysere og producere information) samt Media literacy (evnen til at anvende digitale medier til at fremfinde, vurdere og formidle information). Selv om Spengler sideordner begreberne, kan man forstå tredelingen som dels et praktisk fundament for dannelse (kendskab til teknologien), dels som kendskab til metoder, og dels som evnen til at omsætte denne viden i egen praksis. Netop dette sidste, dannelsesprocessen, som finder sted i lærings- og sociale situationer i et samspil med vejleder og medstuderende, lader sig ikke måle med de redskaber, vi har anvendt. Vi berører emnet $\mathrm{i}$ diskussionen om de studerendes kommunikative praksis, men koncentrerer os i øvrigt om forskellige aspekter af Information literacy 
samt Computer literacy forstået som kompetence i at vælge egnede værktøjer snarere end som helt simpel betjening af teknologien.

\section{Undersøgelsen}

Undersøgelsen af de studerendes brug af it i projektarbejdet bestod dels i en spørgeskemaundersøgelse og dels i en række efterfølgende interviews.

Spørgeskemaundersøgelsen blev indledt med en pilotundersøgelse med fem deltagere, ud fra hvis besvarelser det endelige spørgeskema blev udformet og distribueret i SurveyXact. Dataindsamlingen foregik fra slutningen af maj 2015 til udgangen af juni 2015, og undersøgelsen blev annonceret via RUC's intranet, RUC's Facebook-side, Roskilde Universitetsbiblioteks websted, i RUC's nyhedsbrev nr. 19, 2015, samt gennem skriftlig henvendelse til samtlige studieledere med opfordring til at informere de studerende om undersøgelsen. Vi modtog i alt 273 brugbare besvarelser, hvilket betyder, at undersøgelsen ikke er repræsentativ. Det havde krævet minimum 367 besvarelser og en fordeling af respondenter på fag, som i højere grad afspejler den faktiske fagfordeling. Alle (daværende) institutter er imidlertid pænt repræsenteret i svarene, ligesom respondenterne dækker stort set alle de fag, som udbydes på universitetet. Svarfordelingen mellem bachelor- og kandidatstuderende er 55/45, hvilket er tæt på den faktiske fordeling på studietrin (59/41).

I spørgeskemaet blev de studerende bedt om i fri tekst at opregne, hvilke IT-værktøjer de havde benyttet i de forskellige faser af deres seneste projekt (gruppedannelse og tilrettelæggelse af projekt, dataindsamling og litteratursøgning/-håndtering, rapportskrivning), samt hvilke IT-værktøjer de havde benyttet i studietiden på RUC, samt før de startede på universitetet. Endvidere blev der spurgt til, hvilket IT-udstyr de benytter, samt om baggrundsoplysninger om studietrin, fag, gruppestørrelse og kontaktinformation. Sidstnævnte var frivilligt. I den efterfølgende dataanalyse (i NVivo og Excel) er undersøgt fordelingen af IT-værktøjer på projektfaser. Undersøgt er også forholdet mellem brug af IT-værktøjer og henholdsvis studietrin og instituttilhørsforhold (som strukturen var i 2015), idet værdierne for enkeltfag generelt er for små til at blive tillagt betydning. Oplysningerne om hardware viste sig at være meget lidt nyttige, da hovedparten af IT-værktøjerne er netbaserede og dermed platformuafhængige. Oplysninger om gruppestørrelse, sammenholdt med fag og studietrin, blev brugt som indikator for, om respondenter med sandsynlighed deltog $\mathrm{i}$ samme projektarbejde. Det syntes kun at være tilfældet i nogle ganske få besvarelser.

Anden del af undersøgelsen bestod af syv semistrukturerede kvalitative interviews, der blev gennemført som gruppe- eller individuelle interviews i september-oktober 2015. Hvert interview varede 45-60 minutter og formede sig som en trin-for-trin kronologisk gennemgang af et komplet 
projektforløb, hvor interviewerne undervejs bad informanterne om at begrunde deres valg og fravalg af IT-redskaber og -services. Otte informanter blev rekrutteret ud fra spørgeskemaet, (ud af 94 som havde opgivet kontaktinformation). Alle otte var på det pågældende tidspunkt studerende på kandidatniveau. Yderligere fire studerende på bachelorniveau blev rekrutteret, fordi et af gruppemedlemmerne tidligere havde udvist stor interesse for RUC's IT-services. Fagligt fordeler informanterne sig på humaniora, samfunds- og naturvidenskab. Otte af dem er mænd, og fire er kvinder. Alle lydoptagelser af interviewene er efterfølgende blevet tematiseret og analyseret ved hjælp af NVivo.

Da datamaterialet er forholdsvis spinkelt, har vi for det første, i det omfang det har været muligt, søgt at validere det med server- og log-data fra de ITservices, RUC tilbyder de studerende. Disse sammenligninger omtales i rubrikken "Praksis i forhold til muligheder" nedenfor. For det andet har vi sammenlignet vores resultater med en nyligt udført undersøgelse fra ITUniversitet i København (ITU) (Andersen, 2015). ITU's undersøgelse adskiller sig fra vores ved at være en ren spørgeskemaundersøgelse, der både omfatter undervisere og studerende. Den viser, at de studerende gør brug af et begrænset antal generelle IT-værktøjer, som går igen på tværs af studieretninger. De mest udbredte af dem er Google Docs, Google Drive, Google Search, Dropbox, Powerpoint, Facebook, LearnIT (som er den lokale betegnelse for Moodle), foruden Skype, Youtube og forskellige Adobeprogrammer. De ITU-studerende bruger primært IT til lagring og organisering, til skrivning og fremlæggelse og visualisering. Som det fremgår af det følgende, er brugsmønsteret ikke afgørende forskelligt fra det, der kan iagttages på RUC. Herudover anvender de studerende mere specifikke værktøjer, der er tradition for at bruge inden for de forskellige studieretninger. På dette punkt svarer ITU-undersøgelsen til resultaterne fra de teknisk-naturvidenskabelige fag på RUC, hvor der også anvendes en del forskellige programmerings- og analyseværktøjer. På sidstepladsen over ITU-studerendes formål med at anvende IT ligger informationssøgning.

\section{Resultater}

Helt overordnet har vi kunnet konstatere, at der ikke synes at være markante forskelle mellem bachelor- og kandidatstuderendes anvendelse af IT-værktøjer. Af størst betydning er nok, at kandidatstuderende foretrækker Google Scholar frem for blot Google. Dette er relevant, da Google Scholar giver adgang til Roskilde Universitetsbiblioteks ressourcer, når de studerende er logget på RUC's systemer. Herudover er der ikke nogen klar progression i løbet af studietiden fra generel til specialiseret brug af værktøjer. Til gengæld er der en tydelig forskel på anvendelse af ITværktøjer, før og efter at den studerende er startet på RUC. Her er det klart, at der foregår en udvikling fra en meget generel IT-anvendelse til mere 
specialiseret brug af faglige/videnskabelige ressourcer. Denne specialiserede brug er imidlertid ikke nødvendigvis særligt omfattende.

Hvad angår software, kan det være nyttigt at skelne mellem generelle ITprojektværktøjer og specialværktøjer. Hvad specialværktøjerne angår, er der naturligvis fagforskelle. Således bruger dataloger og HumTek-studerende programmeringsværktøjer, biologistuderende søger litteratur i PubMed, og journalistik- og kommunikationsstuderende nævner oftere Infomedia end andre grupper af studerende. Men når det gælder de generelle ITværktøjer, som udgør langt størstedelen af de produkter, der nævnes, er det svært at få øje på fagforskelle. I dataanalysen har vi derfor slået studietrin og fag sammen, så vi dermed præsenterer et enklere og dermed også mere robust materiale.

Det mest slående indtryk af undersøgelsen er, at de studerende anvender et relativt beskedent repertoire af IT-værktøjer, at nogle få værktøjer er meget dominerende, samt at kun nogle af disse kan betegnes som akademiske IT-værktøjer. Figur 1 illustrerer anvendelsen af de ti mest populære IT-værktøjer, fordelt på de forskellige arbejdsfaser i et projekt. Roskilde Universitetsbibliotek, folkebiblioteker og bibliotek.dk regnes med som IT-værktøjer, da søgning, databaser og til dels samlinger er digitale.

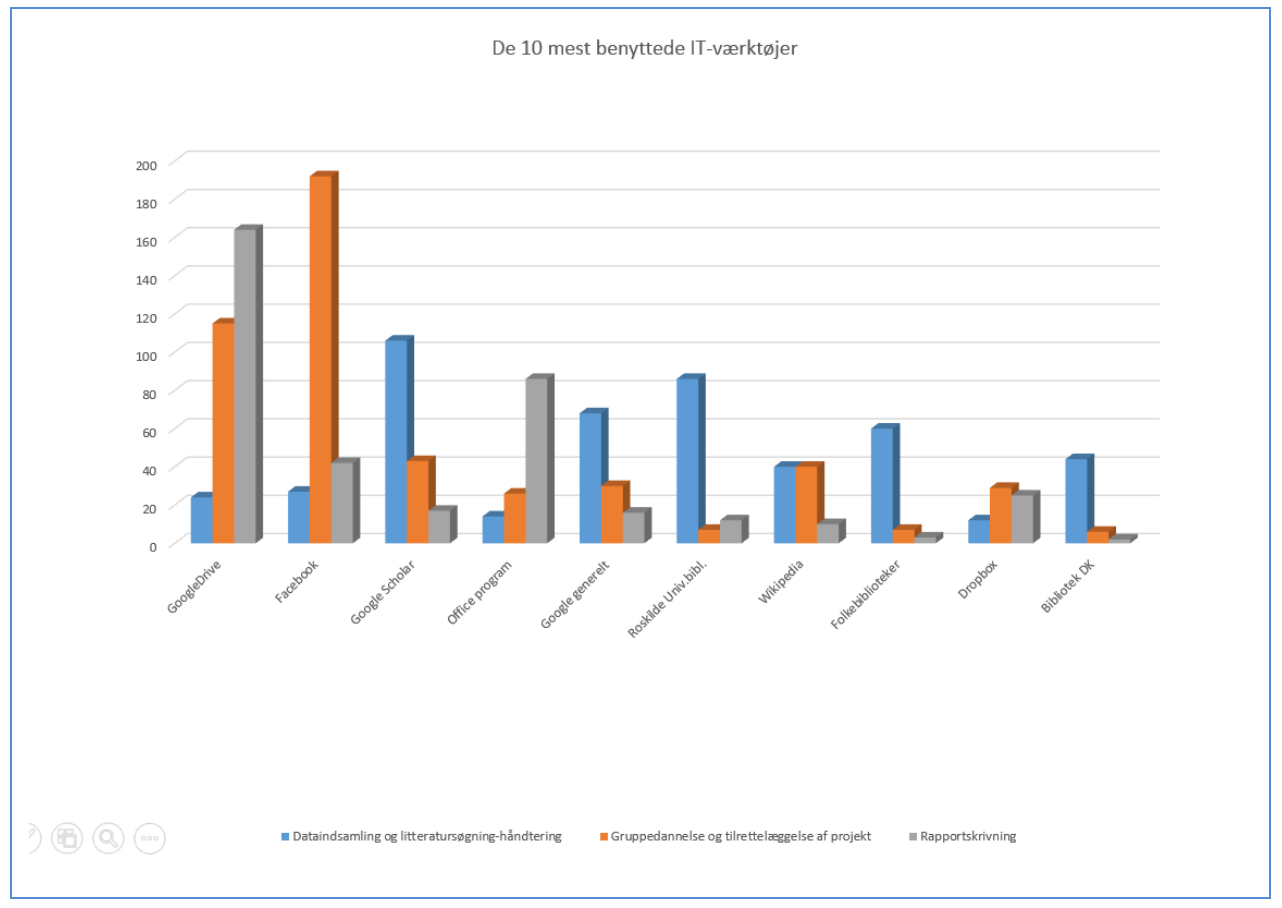

Figur 1. De ti mest benyttede IT-værktøjer i RUC-studerendes projektarbejde. 


\section{Gruppedannelse}

På dette trin i projektarbejdet skal der skelnes mellem de organisatoriske rammer og de forhandlinger blandt de studerende, som fører til dannelsen af grupperne. Hvad det første angår, indgår der teknologi. Det kan være i form af e-mails fra sekretæren med praktiske oplysninger om tid og sted og med projektforslag fra vejledere. Det kan også være projektforslag formidlet af gruppedannelsens proceskonsulenter gennem LMS'et Moodle eller samarbejdsværktøjet Mahara, hvor de studerende har mulighed for at kommentere. Det kan endvidere være gennem fagets eller husets Facebook-gruppe. Ud over at distribuere praktisk information tjener den fælles Facebook-gruppe også til at orientere studerende, som ikke har været til stede under hele gruppedannelsesprocessen, og der findes eksempler på, at vejledere bruger den fælles gruppe til at præsentere sig over for de studerende. Den fælles Facebook-gruppe er i det hele taget en vigtig informationskilde gennem hele semesteret, og det synes faktisk nødvendigt at være en del af den fælles Facebook-gruppe for at kunne klare sig:

"Da vi startede på RUC på 1 semester, var der et par stykker, som ikke var på Facebook, som altså hurtigt fandt ud af, at det var squ nødvendigt for at gå på RUC ... du får så meget information fra alt muligt, og det foregår over Facebook det hele... de blev tvunget lidt ind i det, kan man sige, for ikke at gå glip af en masse information". (Interview 3, Hanne, 05:04)

Den tidlige introduktion på studiet af Facebook betyder, at de studerendes kommunikationsvaner formes med udgangspunkt i det velkendte, hvilket fremgår af denne diskussion:

Hanne: "Folk kender Facebook i forvejen og ved præcis, hvordan sådan en gruppe skal stykkes sammen ..., og på den måde at det kommer til at fungere, og folk skal ikke til at sætte sig ind i et eller andet program som Mahara .... Altså, de fleste studerende er på Facebook alligevel. Så kan man lige se, om der er en i gruppen, der har skrevet ... " Georg: "Noget af det første jeg fik at vide, da jeg startede på Humtek var, at der var lavet en Humtek-gruppe for dem der var startet op samtidig med mig, vi kunne gå ind på denne her gruppe på Facebook og se på aktiviteter for opstartsperioden, så det var faktisk et af de første medier, vi blev sat overfor" ... "Det er stadig det første sted man lærer at kommunikere på universitetet". (Interview 3, 8:52)

Hvad angår møderne og diskussionerne under gruppedannelsen, er der bred enighed om, at der ikke anvendes teknologi. Frem til gruppedannelsen vil nogle gruppemedlemmer have søgt at spore sig ind på et emne gennem søgning i RUC’s jobbank, Google, Google Scholar eller søgemaskinen 
Summon, men i de fysiske møder kan der højst være tale om at medbringe udskrifter af projektforslag og hus-information.

Når først projektgruppen er dannet, vil langt de fleste oprette en privat Facebook-gruppe for projektgruppen. Det er en nem løsning, fordi alle er på Facebook i forvejen - eller kommer det, hvis de vil klare sig på RUC. En enkelt informant fortæller, at to gruppemedlemmer, som ikke er på Facebook, får orientering per telefon om, hvad der er skrevet i Facebook. Mange checker Facebook ofte i løbet af en dag, og smartphone-brugere kan få notifikationer sendt direkte. Det er en-til-mange kommunikation, og man kan se, om andre har læst et indlæg. Derfor er det en effektiv måde at holde sig orienteret om gruppens arbejde på, og det er et middel til at undgå den følelse af isolation, som kan optræde i netbaseret samarbejde:

"Hvis personen ikke har reageret, så bliver jeg nødt til at bruge noget andet, og måske bliver jeg nødt til at ringe til dem, eller skrive en mail. Men der er jo ikke rigtig nogen, der kan finde ud af at checke deres mail. Der går lige et døgns tid før folk har kigget på en mail". (Interview 1, Arne, 05:40)

Når man endnu ikke kender hinanden godt, er det også en mindre personlig måde at basere kontakten på, end det er at udveksle telefonnumre. Facebook-gruppen bruges til koordinering af aktiviteter (hvor fx et "like" kan bruges til at bekræfte en aftale), til at samle op på aftaler fra gruppemøder, til at give beskeder, til idégenerering, til at gøre opmærksom på relevant litteratur, samt naturligvis til social kommunikation. Facebook kan bruges til diskussioner, men flere peger på, at kommunikationen i tråde hurtigt bliver uoverskuelig. Herudover anses Facebook for at være en uegnet platform for diskussion, ligesom man ikke kan sortere i informationen. Dog kan det være godt nok til korte meningsudvekslinger om konkrete problemer, fx under rapportskrivning, men ikke til at håndtere egentlige samarbejdskonflikter. Endvidere kan Facebook-gruppen bruges til "nudging" i form af påmindelser om også at checke andre fælles medier. Facebook gør det desuden muligt at håndhæve justits i gruppen:

"Der var en pige fra vores gruppe, som ikke rigtig mødte op. Vi kunne godt se, at hun var ikke rigtig interesseret i den gruppe, vi havde oprettet. Og så på et tidspunkt, vi skriver til hende "hvor er du henne?", og skriver hun, hun er til forelæsning - på RUC. Og så kan man så se, at beskeden er sendt fra Avedøre, hvor hendes kæreste bor. Så man kan også bruge det lidt som sådan overvågning ... Også fordi man kan se, folk har set ens opslag." (Interview 3, Erik, 12:45) 
Kontakten med vejleder foregår ikke via Facebook, men gennem e-mail og i nogle tilfælde over telefon. Flere informanter skelner mellem en mere formel kommunikation med vejlederen og en uformel, faglig og social kontakt med gruppen via Facebook. Facebook-gruppen fungerer desuden som et frirum for gruppens medlemmer. Enkelte vejledere benytter Mahara som medium og arkiv i gruppevejledningen, mens RUC's gamle samarbejdssystem, BSCW, stadig benyttes som virtuelt rum for vejledning i enkelte miljøer.

Mens valget af Facebook som værktøj for gruppemedlemmerne forekommer nærmest selvfølgeligt, kan der i gruppen herske usikkerhed om, hvilke andre IT-værktøjer, der skal inddrages i gruppearbejdet. Det generelle indtryk fra interviewene er, at grupperne vælger at benytte de IT-værktøjer, som enten alle kender på forhånd, eller som er lette at sætte sig ind i. Der optræder ikke i interviewene nogen fagligt begrundet systematik i valget, og overvejelser om IT-valg har ikke betydning for selve gruppedannelsen. Men i flere udsagn fremgår der en uvilje imod at bruge tid på at lære nye systemer, fx:

"... En oplevelse af, at de her programmer mere tager tid, end de giver tid, fordi der skal bruges noget tid på at lære det. Og så kommer sædvanen: 'Jeg har jo gjort det her før, og det fungerer jo fint'”. (Interview 5, Jørgen, 35:24)

Informanten Jørgen er særdeles it-kyndig og vil gerne tage nye værktøjer i brug, men:

"Det kan godt være, at jeg vil bruge det selv. Men ... der er en barriere med at overtale andre og få andre til at lære det og få andre til at blive indstillet på det ... Det er ikke alle, som er itferme overhovedet, og mange synes måske bare det at lære et nyt program, det bliver bare sådan: 'OK, vi har også rigtig mange andre ting, vi skal nå, og hvorfor skal jeg så bruge tid på det her program'? Og så kan det være, at man sidder og siger: 'ja, ja, men det er jo så også tidsbesparende i sidste ende'. Men igen, det kan være svært at få dem overtalt". (Interview 5, Jørgen, 32:10)

Jørgen og et andet gruppemedlem har dog ikke givet op og vil på et kommende gruppemøde holde et oplæg om det program, de gerne vil have hele gruppen til at bruge. Andre særligt IT-kyndige synes derimod at være tilbageholdende med at insistere på at introducere nye værktøjer, fordi det er en belastning for dem selv:

"Bare fordi jeg kan finde ud af det, betyder det ikke, at de fire andre kan finde ud af det, og ... så fungerer man som it-supporter, 
hvis man skal introducere sådan nogle ... det tager bare så meget af tiden, hvis man sidder og skal hjælpe folk igennem, hver gang man skal bruge et nyt værktøj" (6:56) ..."Det er nok nærmere det der med, at man favner bredt, og man siger det her skal folk kunne finde ud af, og det skal de selv kunne finde ud af at styre, eller jeg skal i hvert fald kunne lave det hurtigt. Og det vil sige, at i stedet for at det bliver folks IT-kundskaber, der definerer, så bliver det den anden vej rundt, sådan så det er, hvilke værktøjer ved jeg, at alle kan bruge, og derfor benytter jeg mig af dem, fordi det er simpelthen fail safe at bruge det den vej rundt". (Interview 1, Arne, 07:43)

Ud over Facebook-gruppen anvendes der tilsyneladende ikke særligt mange IT-værktøjer til at styre projektet. Mahara (som har erstattet BSCW) nævnes sjældent og ikke i forbindelse med projektkoordinering. Kun 26 respondenter på spørgeskemaet anfører kalenderprogrammer. Langt hovedparten af disse nævner Google Calendar, nogle få Doodle til mødeplanlægning, og kun to nævner RUC's kalenderprogrammer. I interviewene er der konsekvent spurgt til brug af kalender, og svarene bekræfter indtrykket fra spørgeskemaundersøgelsen. Således laver én informant et aftale-diagram i Google Sheets, en anden et tilsvarende dokument i et tekstbehandlingsprogram og fortæller i øvrigt, at gruppen har en koordinator, som aftaler mødetidspunkter med vejleder ud fra gruppemedlemmernes udmeldinger. En enkelt informant har på et tidspunkt deltaget i et projekt, hvor man til slut indførte Google Calendar "som gjorde tingene 20 gange nemmere", mens en anden udtaler sig stærkt kritisk om delte kalendere. Fra studenterpolitisk arbejde kender hun dem som noget, folk glemmer at skrive aftaler ind i.

\section{Arbejdsprocessen}

Det foretrukne fælles IT-værktøj er Google Drive og først og fremmest dets tekstbehandling (Google Docs). Mange studerende kender programmet i forvejen, og hvis ikke, er det let at komme i gang med at bruge det. Med Google Docs foregår backup automatisk, så man ikke mister sit arbejde, og med den indbyggede "revision history" er der styr på versioneringen, så man eventuelt kan vende tilbage til en tidligere udgave af dokumentet. Endvidere er det som fuldt netbaseret program uafhængigt af computerplatforme. Afgørende vigtigt er det, at det er muligt for flere at arbejde samtidigt på ét dokument. Flere informanter nævner, at de på et tidspunkt har benyttet Dropbox til fildeling, men er holdt op med det, da der netop mangler mulighed for tidstro samarbejde. Også muligheden for at skrive kommentarer til teksten er vigtig. 
Fælles for alle informanternes udsagn er, at Google Drive er et stærkt værktøj i de sene faser af skrivearbejdet, hvor projektets enkeltdele samles til et hele. Dette hele redigeres i fællesskab, gerne sådan at gruppemedlemmerne samles om en projektor og gennemgår rapporten afsnit for afsnit. Nogle læser hele rapporten højt og lader gruppemedlemmerne kommentere undervejs, andre uddelegerer opgaver (som for eksempel opsætning, tegnsætning og korrektur) og gennemgår opgaven bid for bid. Vejen til sammenskrivningen kan variere. Alle informanter beretter om distribution af opgaver, hvor hvert gruppemedlem arbejder individuelt på et kapitel eller et emne. Et par stykker foretrækker at skrive på pc'en og først dele teksten med andre, når den er klar til at blive vist frem. Andre skriver konsekvent kun i Google Drive. Der er forskellige strategier for at samle de enkelte tekststykker. En omtaler en praksis, hvor et dokument rykkes frem fra mappe til mappe, fra "undervejs" til "redigeret" og "færdigt", for til slut at blive integreret i rapporten. Herudover skal mindst to andre gruppemedlemmer godkende teksten, før den flyttes. En anden fortæller, at man læser hinandens tekster undervejs, således at mindst to andre kommenterer og retter den enkeltes bidrag, og at helheden til sidst redigeres af to redaktører. En tredje forklarer, at når to dokumenter af individuelle forfattere samles, arbejder begge videre på det nye dokument.

I de allersidste faser af projektarbejdet flyttes dokumentet fra Google Docs til tekstbehandling. Det sker primært, fordi pc'ens tekstbehandling er bedre til formatering, herunder til at oprette indholdsfortegnelse og litteraturhenvisninger. Google Docs kan angiveligt også have svært ved at håndtere meget store filer.

\section{Fildeling}

Facebook og Google Drive bruges også til at dele filer, ligesom Dropbox anvendes til at dele ikke-redigerbare dokumenter. I nogle tilfælde gemmes filer i flere medier som en art sikkerhedskopiering. Samtlige interviewpersoner deler artikler i de tre web-tjenester, og flertallet deler også personfølsomme data såsom lydoptagelser og transskriptioner af interviews. På Facebook er det almindeligt at uploade en artikel eller et link til den med opfordring til, at gruppemedlemmerne læser den inden næste møde. En konstaterer, at Facebook har den fordel, at man kan se, hvilke andre gruppemedlemmer, som faktisk har åbnet filen. På Google Drive deles først og fremmest artikler, men en enkelt informant indrømmer, at han scanner bøger og deler dem med gruppemedlemmerne for at spare penge til bogindkøb. Nogle opbygger en egentlig biblioteksmappe i forbindelse med projektet. Under interviewene er der spurgt ind dels forståelsen af ophavsret, dels til beskyttelse af data. Hvad ophavsret angår, har flere en common-sense forståelse: 
"Der har jeg altid tænkt, at det må jeg godt, fordi det lå på nettet i forvejen. Det er den måde, vi fandt det. Eller for eksempel hvis det er noget fra de forskellige biblioteker, så er det noget, jeg som studerende har adgang til, derfor de mennesker som jeg deler med, de er også studerende, så de må også have adgang til det, have lov. I forhold til ... det store stygge net, hvor man også kan finde forskellige bøger og sådan noget, det er igen, jeg tror meget, at jeg er gået ud fra, jeg har ikke i sinde at misbruge det, så det er i orden." (Interview 6, Karen, 57:00)

Som udbyggende argumentation anføres, at der jo er tale om en lukket gruppe, så uvedkommende ikke får adgang, at det er afgørende vigtigt, at alle har adgang til de samme kilder, at det er upraktisk for alle gruppemedlemmer at skulle have besvær med at skaffe en tekst (og derfor gør man det ikke), samt at materialerne bliver fjernet, når de ikke længere er i brug.

Der er imidlertid også eksempler på, at "nyttefilosofi" dikterer bevidst omgåelse af reglerne:

"Personligt er jeg nok lidt ligeglad. Den etiske overvejelse er nok mest ... at alt hvad der kan gavne det her projektarbejde, det deler jeg ... Jeg ved egentlig godt, at jeg ikke må dele. Jeg har sådan en service der hedder [Navn], hvor jeg kan gå ind og søge på litteratur og jeg må egentlig ikke dele med andre ... men ... det ville være dumt [i gruppearbejdet] ikke at sige: 'jeg kan altså lige skaffe den her bog af Bourdieu, som er udlånt på samtlige biblioteker. Den kan jeg lige lægge op i drevet og så kan vi alle sammen læse den'. Det plejer jeg også at bruge som argument: Jeg er ordblind, men jeg kan skaffe masser af god litteratur". (Interview 5, Jørgen, 36:54)

Hvad angår deling af personfølsomme interview-data er ingen af informanterne opmærksomme på, at det er problematisk at lagre dem i en cloud-tjeneste, mens de til gengæld er yderst opmærksomme på betydningen af at anonymisere kilderne for at beskytte informanterne.

Endelig er der spurgt, om informanterne er blevet introduceret til regler om ophavsret og omgang med personfølsomme data. De fleste erklærer, at de ikke har modtaget eller erindrer at have modtaget en sådan instruktion. Et fătal informanter har fået den gennem metodeundervisning eller gennem et oplæg, vistnok fra en vejleder, og en forklarer, hvordan der er opsat regler for kopiering ved kopimaskinerne. 


\section{Litteratursøgning}

Digitale bibliotekstjenester fylder meget i det samlede billede af, hvilke værktøjer de studerende bruger i projektarbejdet, men overgås alligevel stort af Google og Google Scholar. Som nævnt viser spørgeskemabesvarelserne en stigning i anvendelsen af Google Scholar på kandidatniveau, og flere af informanterne er bevidste om, at de kan søge i RUC's ressourcer via Google Scholar, når er er logget på via universitetet. En enkelt af interviewpersonerne beskriver en "dannelsesrejse" $i$ informationssøgning fra studiestart til et niveau, hvor Google Scholar ikke længere altid kan opfylde informationsbehovet:

"På de første semestre ... anede vi jo ikke, hvad vi lavede. Der var det hele meget nyt, og Google ved man, hvad er" ... "Jo længere, jeg er kommet i mine studier, jo mindre synes jeg, at Google Scholar kan det, jeg gerne vil have den til. Det giver bedre mening for mig for eksempel at bruge biblioteket, enten herude på RUC eller Rex, fordi ... jeg synes i højere grad, jeg kommet til kort med Google Scholar". (Interview 6, Karen, 13:54)

Hverken data fra spørgeskema eller interviews peger imidlertid på, at en sådan udvikling foregår universelt, og specielt brugen af de fagdatabaser, som udbydes af bl.a. Roskilde Universitetsbibliotek står svagt. Blandt respondenterne på spørgeskemaet har kun hver syvende sat navn på en database som Ebscohost, Jstor, Pubmed, Sage, Scopus eller Web of Science. Et tilsvarende antal har benyttet sig af "databrønden" Summon. Ingen af interviewpersonerne nævner en specifik database.

I interviewene forklares en række forskellige søgestrategier, af hvilke vi særligt vil fremhæve to. Den ene tager udgangspunkt i dokumenter og har karakter af en kædesøgning. Her søges der enten i tidligere studenterprojekter om et givet emne. Disse er tilgængelige via online-arkivet Rudar (rudar.ruc.dk). Eller der foretages opslag i Wikipedia for at se, hvilke kilder der er brugt i opslaget. Denne strategi benyttes dels til at søge inspiration til indkredsning af emne, teoretisk ramme samt metoder og dels til at finde frem til grundlæggende litteratur:

\footnotetext{
"Så kan du gå ind på Rudar og se, om der er nogen, som har skrevet noget lignende, hvilken litteratur bruger de. Så kigger du på litteraturlisten i de her projekter og undersøger den". (Interview 1, Bent, 13:57)

"Så søger vi efter andre rapporter, som er skrevet om det samme for at komme ind og lige få en ide. Det kan godt være lidt svært når man ikke lige har en forståelse af de teorier, vi gerne vil
} 
arbejde med. Så det er faktisk noget af de første, vi gør".

(Interview 2, Dorthe, 6:38)

"Det er nemmere at kværne to sider af Wikipedia og forstå helheden. Det kan godt være, den er forkert, men så kigger du på referencen, og så kan du gå ind på de links, der er der inde. Det finder jeg virkelig fornuftigt at starte ud med". (Interview 1, Bent, $13: 44)$

De studerende er meget opmærksomme på, at Wikipedia-artikler ikke i alle tilfælde er troværdige, samt at den emnemæssige dækning er svingende. Men til simple opslag såsom begrebsafklaringer eller årstal eller til at finde hovedværker finder de den brugbar. Hverken i interviews eller spørgeskemadata omtales fag-encyklopædier, og ingen af informanterne nævner selv betydningen af literature reviews.

Hvad angår fundene af litteratur, er det almindeligt dels at søge efter titler på biblioteker og dels at "google" videre på forfatternavne for at se, hvad de ellers har skrevet:

"Hvis man tager eksemplet med Svend Brinkmann, så vil jeg gerne have fingre i noget mere af ham. Så søger vi på ham, og så ser vi, hvad der sker." (Interview 6, Karen, 12:21)

Den anden hovedstrategi består i at søge på emneord, men ingen af informanterne gør rede for, at de benytter sig at en systematisk og tilrettelagt emnesøgning. Her er strategien at forfine søgningen ved at tilføje og evt. udskifte søgeord. Men ingen af interview-personerne kan gøre rede for en egentlig søgestrategi, ligesom begreber som trunkering og boolske operatorer forekommer at være meget lidt kendt:

"Jeg har prøvet et projekt, hvor vi skrev om, hvordan EUdirektiver blev implementeret i medlemslandene, og det var meget svært at finde en indgangsvinkel. ... Så måtte vi ind på Google Scholar og søge virkelig bredt, før vi overhovedet fandt det, der var perfekt at skrive om. Så der havde vi jo ikke nogen keywords, men det fungerede mere som en tragt at gå ind på Google Scholar, for man kunne jo se, 'nå, det der kunne være interessant', så tilføjer man det keyword, og så finder man en anden artikel; 'det kunne også være interessant', så tilføjer man det keyword og så..., men man går mere induktivt til det. Man kigger virkelig bredt, bruger to-tre dage på det og indsnævrer sig gennem (den og den artikel)”. (Interview 5, Jørgen, 15:59) 
Men de der koder og alt det der, at man kan lave semikolon og alt sådan noget der, det har jeg sgu ikke lært endnu. Om end jeg egentlig burde have fundet ud af det på der litteratursøgningskursus". (Interview 5, Jørgen, 17:00)

Uanset hvilken søgestrategi der benyttes, er informanterne opmærksomme på, at der knytter sig en kvalitetsvurdering til udvælgelsen af artikler. Her går fx. en efter materiale, som er peer reviewed, en anden benytter citationsfunktionen i Google Scholar og forholder sig efter eget udsagn til, hvor pålidelig og god informationen er i forhold til det, han skal bruge den til.

\section{Referencehåndtering}

I spørgeskemaundersøgelsen skriver kun hver sekstende respondent, at hun har benyttet et dedikeret reference-håndteringsprogram. Flest har benyttet Mendeley, nogle andre Zotero og forskellige andre systemer. Tallet er imidlertid stærkt misvisende, fordi mange studerende arbejder systematisk med referencer vha. et tekstbehandlingssystem (først og fremmest MS Word), mens andre benytter en netbaseret referencegenerator eller Google Books' reference-generator, og atter andre følger et forlæg:

"Jeg har fået et dokument af en underviser, som gik rigtig meget op idet. Så det har jeg skrevet ud, og så kigger jeg på det. Der er ikke noget IT ind over". (Interview 1, Arne, 30:12)

"Jeg har oplevet virkeligt mange forskellige måder at referere på. Men så havde jeg [RM] som underviser, og han sagde: sådan her gør I. Punktum. Og siden da har jeg bare fulgt den model”. (Interview 1, Bent, 30:30).

Interessen for referencesystemer er begrænset, og flere opfatter dem som tidskrævende og besværlige at sætte sig ind i:

"Det har noget omkring tid at gøre, når jeg skriver en kilde ind, og der skal stå Poulsen komma et-eller-andet, så tænker jeg, den tid det tager mig at sætte den ind der og lige smide den ned i litteraturlisten, det går hurtigere, end jeg skal sætte mig ind i et program". (Interview 3, Finn, 42:33)

Denne bekymring deles af Karen:

"Jeg kunne godt være bekymret for, at det ville være mere besværligt for mig at sætte mig ned og lære det her program, end det er rent faktisk at lave den liste og så bare huske at lave de der referencer undervejs". (Interview 6, Karen, 36:27) 


\section{Aflevering og eksamen}

De afsluttende faser af projektarbejdet har været berørt i interviewene, men ikke i spørgeskemaet, da der i forhold til aflevering ikke gives et valg. Samtidig er den mundtlige eksamen i høj grad et spørgsmål om faste konventioner på institutter og fag. Hovedindtrykket er, at de studerende er glade for digital aflevering, som betyder en arbejdsmæssig lettelse. Men lidt overraskende - vælger næsten alle informanter efter aflevering af skrive projektrapporten ud på papir og at medbringe papirversionen til eksamen. Begrundelsen er generelt, at det virker uhøfligt at medbringe en pc og sidde gemt bag en skærm i gruppediskussionerne. Nogle peger også på, at teknikken kan svigte på et kritisk tidspunkt. I et enkelt tilfælde var valg af medie ikke til diskussion:

[bedømmerne havde opgaven] "printet ud, så vidt jeg kan huske. Vi er blevet bedt om at printe det ud, så vi allesammen kom med hver vores opgave". (Interview 2, Dorthe, 42:45)

Brug af præsentationsgrafik i forbindelse med eksamensoplæg synes heller ikke at være almindeligt udbredt på RUC. Man medbringer hellere et oplæg på papir. Kun to af de 12 informanter har benyttet PowerPoint eller Prezipræsentationer i en eksamenssituation. Med forfatternes kendskab til andre universiteter ud fra censorarbejde, stikker RUC ud som meget konventionsbundet, hvis vores resultater står til troende.

\section{Praksis i forhold til muligheder}

De praksisser, der er redegjort for ovenfor, harmonerer ikke særlig godt med de muligheder, de studerende har for frit og gratis at benytte universitetets forskellige digitale tjenester. Med forbehold for at spørgeskemaundersøgelsen ikke er repræsentativ, samt at tallene kun i få tilfælde har kunnet valideres med log-data for brug, gengives nedenfor i Tabel 1 en oversigt over de vigtigste IT-værktøjer, RUC stiller til rådighed for studerende og ansatte sammen med tallene for anvendelse ifølge besvarelserne. Beregningen er foretaget pr. respondent (og ikke det samlede antal svar, hvor et værktøj kan optræde i flere projektfaser), og der er registreret enhver brug af værktøjet i løbet af studietiden.

Som nævnt ovenfor har vi, hvor muligt, søgt at validere vores resultat med log-data for faktisk brug af de forskellige, omtalte tjenester. Disse omfatter alle RUC-brugere (studerende, undervisere og administrative medarbejdere), og det har ikke ladet sig gøre at afgrænse tidsmæssigt på en ensartet måde. Men det fremgår, at

- der i 2015 frem til begyndelsen af december ifølge udbyderen DEiC har været 49 aktive brugere af Adobe Connect (ud af 582 registrerede 
brugere). Logdata for Lync gemmes kun i 24 timer og kan derfor ikke bruges til sammenligning;

- der i perioden medio-september 2014 til ultimo januar 2016 er sket en tilvækst på ca. 1000 Mahara-brugere (til 3986), men at kun 20-40 logger ind på en normal dag (yderpunkterne er hhv. 251 og 0), samt at der i kun i 18 ud af 358 grupper (i sig selv et lavt antal) har været skrevet 10 eller flere indlæg;

- af de otte "databaser" nævnt i spørgeskemabesvarelserne, befinder seks af dem sig på bibliotekets liste over Top 10 Referring Sources (de databaser som brugerne har benyttet mest i forsøg på at skaffe sig adgang til artikler eller andet indhold i fuldtekst). Fælles for fem af de seks databaser er, at brugen af dem er faldet over de sidste fire år. Dog er Pubmed-anvendelsen steget et enkelt år for siden at falde igen. Selv anvendelsen af Google Scholar er faldet, fra 12\% i 2012 til 7,5\% i 2015. Disse tal dækker kun over brug, hvor browseren er indstillet til at have biblioteksadgang til Roskilde Universitetsbibliotek og kan dermed variere en del fra spørgeskemarespondenternes beskrevne brug. Summon-brugen er som den eneste steget markant. I 2012 blev den brugt i 19\% af søgningerne, og i 2015 var dette tal steget til 50,4\% ud af de ti mest brugte databaser. Sage (forlags-websted), Jstor (arkiv med en femårs embargo) og Infomedia (arkiv) befinder sig ikke på listen over Top 10 Referring Sources. Infomedia har dog fra 2014 til 2015 haft en 68,5\% stigning i antallet af overskriftsvisninger.

Som nævnt har det været vanskeligt at fremskaffe brugerstatistikker, der kan sammenholdes med resultaterne fra spørgeskema- og interview-undersøgelserne. Men de få værdier, det er lykkedes at fremskaffe, synes ikke at modsige de indtryk, som de to undersøgelser efterlader.

Hvad angår IT-værktøjer uden for RUC-regi, så er der millioner af programmer og apps på markedet. Selv om kun en meget lille del af dem er oplagt studierelevante, udgør disse fortsat en mængde, som ingen kan overskue, og tilvæksten er så voldsom, at ingen kan holde sig ajour med udviklingen. Det er en verden, hvor anbefalinger og "heldige fund" i høj grad betinger adoption af software, og hvorfra især de studerendes bidrag til fornyelse af IT-praksisser burde komme.

Men det bemærkes, at der i spørgeskemaundersøgelsen kun sættes navn på en håndfuld programmer, som ret få studerende inddrager for at organisere og støtte projektarbejdet. Under interviewene er der blevet spurgt ind til disse, når det var muligt. Ud fra disse ganske få udsagn er indtrykket, at der gerne er tale om enkelte studerende, som har fundet noget smart, som de selv gerne vil bruge, mens det er vanskeligt at overtale den samlede gruppe til at tage et nyt værktøj til sig. 


\begin{tabular}{|c|c|}
\hline Samarbejde & $\begin{array}{l}\% \text { har på et tidspunkt } \\
\text { anvendt }(n=273)\end{array}$ \\
\hline Mahara & 3,3 \\
\hline BSCW & 13,6 \\
\hline Outlook & 1,5 \\
\hline \multicolumn{2}{|c|}{ Litteratursøgning \& referencehåndtering } \\
\hline $\begin{array}{l}\text { Databaser: Ebscohost, Jstor, Pubmed, } \\
\text { Sage, Scopus, Web of Science }\end{array}$ & 14,7 \\
\hline Summon & 13,9 \\
\hline Mendeley & 4,0 \\
\hline Endnote, Reference Manager & 1,1 \\
\hline Infomedia & 9,2 \\
\hline \multicolumn{2}{|l|}{ Kommunikation } \\
\hline Lync: ip-telefoni, videokonference & 0 \\
\hline Adobe Connect videokonference & 0 \\
\hline Filesender & 0 \\
\hline \multicolumn{2}{|l|}{ Analyse } \\
\hline NVivo (introduceret ultimo 2014) & 0 \\
\hline Spss & 5,1 \\
\hline SurveyXact & 1,1 \\
\hline
\end{tabular}

Tabel 1. Anvendelsesgrad af RUC's IT-værktøjer. 


\section{Hvorfor står det sådan til?}

Hvis ovenstående redegørelse står til troende, synes et flertal af de RUCstuderendes Computer Literacy generelt ikke at være modsvaret at en akademisk set acceptabel Information literacy og Media literacy. Sammenholdt med den internationale litteratur og ITU-undersøgelsen, som vi har refereret tidligere, er iagttagelsen måske ikke bemærkelsesværdig. Vi har blot leveret et eksempel fra universitetsverdenen på, at de "digitalt indfødte" slet ikke er så softwaremæssigt avancerede, som det populært antages. RUC markerer sig således ikke specielt negativt hvad angår ITanvendelse. Men der er ikke meget at glæde sig over, når der samtidig tegner sig et billede af, at de studerende ville kunne udføre deres projektarbejde mere effektivt, mere professionelt og nok så væsentligt også generelt mere lovmedholdeligt, hvis de fik en grundlæggende og systematisk akademisk IT-skoling.

Den mest indlysende og meget brede forklaring på tingenes tilstand er, at akademisk IT-skoling ikke kommer af sig selv. I det følgende kvalificeres og anskues dette udsagn på forskellige niveauer.

Ud fra en overfladisk betragtning spiller arbejdspres en væsentlig rolle. Selv om et typisk projektarbejde strækker sig over et helt semester, er tidsplanen ifølge de studerende presset. Det er fx. begrundelsen i det nedenstående for at springe arbejdet med bibliografiske databaser over:

"Jeg tror måske, det ville være bedre akademisk arbejde, hvis vi havde været mere grundige med at afsøge hele feltet og virkelig sorteret ud i alt sammen og virkelig havde en idé om, hvad alt sammen er, men problemet med gruppeprojekterne er også bare, at vi har så ekstremt lidt tid, så tit handler det også bare om at komme i gang så hurtigt som muligt og bare nå at læse det, man nu kan nå at læse", (Interview 4, Ivan, 12:23)

Selv om tidens krav om effektivitet og fremdrift (og de dertil hørende styringsredskaber) meget vel kan tænkes at indvirke negativt på viljen til og mulighederne for akademisk fordybelse, er det højst en medvirkende faktor til den utilstrækkelige akademiske IT-skoling. Uddannelse i almindelighed og projektarbejde i særdeleshed er i reglen kendetegnet ved perioder med stor arbejdsbelastning. Men netop teknologien burde her kunne bidrage til, at den enkelte kan udrette mere ved egen hjælp samt få aflastning til at overkomme rutineopgaver. Et eksempel på en rutineopgave er elektronisk referencehåndtering.

Her spiller så arbejdsrutiner og vaner ind. Bedømt ud fra det materiale, vi har indsamlet, synes det ikke at være almindeligt, at er stilles krav til de studerendes brug af IT i en faglig sammenhæng. Der mangler rollemodeller og eksemplariske anvendelser. Men når disse optræder, er de studerende 
ikke sene til at følge dem. Et lidt ironisk eksempel er anvendelsen af Facebook som kommunikationsmiddel på et fag eller i et hus. I udgangspunktet forekommer det at være en god idé, men når de studerende tager løsningen til sig som omdrejningspunkt for gruppearbejdet, ender den med at blokere for andre, mere velegnede værktøjer.

De studerende er i høj grad overladt til selv at udforme digitale arbejdsrutiner. Her er det væsentligt at slå fast, at betegnelsen "digitalt indfødt" er meningsløs. IT-kompetencerne og viljen til at eksperimentere med ny teknologi varierer meget. Eksperimenter kan synes nok så lovende for at lette projektarbejdet, men ildsjælene viger ofte tilbage for at undgå at blive IT-supportere for de øvrige, mindre teknologi-motiverede gruppemedlemmer. Derfor vælger projektgruppen typisk de værktøjer, som alle kender i forvejen og har gode erfaringer med:

"Vi har brugt seks semestre på at beherske nogle IT-former som fx Google Drive og Facebook, og hvordan man skal gøre det. Det kan vi meget godt nu. Så det ville være lidt underligt lige pludseligt at skifte IT-platform, selv om det måske vil var bedre". (150914, Bent, 35:34)

Ovenstående udsagn antyder desuden en god portion bekvemmelighed, og det er fristende at forbinde denne med den selvopfattelse som "forbruger af uddannelse”, som vi gang på gang er stødt på i interviewene, og som i øvrigt bekræftes fra anden side (bl.a. Jensen, 2015). Der er en tendens, også blandt RUC-studerende, til at forklare deres situation ud fra en skoleterminologi. Universitetet er således "en helt anden form for sted, hvor man skal gå i skole", hvor de studerende er "elever", der udfører "skolearbejde" og har "lektier for til næste gruppemøde", og hvor det selvstændigt at skulle tilrettelægge sit arbejde ikke nødvendigvis er attraktivt. Flere informanter henviser til lektionssystemet Lectio, som de kender fra gymnasietiden, og fremhæver, hvordan sådan et system kan bidrage til at skabe faste, trygge rammer:

"Lectio for studerende kunne være så exceptionelt fedt eventuelt at lave, .... Altså have de der fem-ni knapper, checke sine eksaminer ... og også have en fælles kalender og et kort over RUC". (02:11) ... Når man tænker Lectio, så tænker man gymnasiet og noget, der bliver skoleagtigt. Og det vil RUC ikke være. Det vil være universitet, hvor folk selv har ansvar. Den møder jeg også rigtig meget: det skal du selv finde ud af. Og der er ingen, sådan lad os prøve på fælles at få en sådan koordinering af, mellem forelæsere og studerende og projektgrupper, at vi har en fælles opgave af at uddanne folk og lave projektarbejde". (Interview 5, Jørgen, 03:04) 
Et andet "vane-argument" er, at en del studerende vurderer, at IT har lav nytteværdi: Det er måske nok et praktisk redskab, men det fylder ikke meget i den samlede mængde af elementer, som indgår i projektarbejdet:

"Teknologien er for mig så lille en del af det. Det fylder rigtig meget, men det er en lille del af et projektarbejde, så det skal bare fungere". (Interview 2, Dorthe, 50:30)

Hvad angår institutionens rolle, tyder en del informant-udsagn på, at dens initiativer har meget begrænset effekt. De studerende kender simpelthen ikke til de nødvendige værktøjer og regler. Biblioteket tilbyder således regelmæssigt kurser i litteratursøgning og referencehåndtering, og flere af informanterne har deltaget i sådanne kurser, men indholdet har ikke virket relevant på det tidspunkt, de deltog i undervisningen. Det samme gælder de meget udbredte IT-introduktioner, som finder sted tidligt i studiet:

"Jeg tror da, at vi er blevet introduceret på første semester" ... "Jeg tror måske også lige, når det er på første semester, der har man så mange andre ting kørende, det er som ind af det ene øre og ud af det andet. Man har simpelthen ikke plads til det".

(Interview 2, Dorthe, 32:29)

Men ud over fejlplacerede kurser synes der også at forekomme egentlige huller i den undervisning, der tilbydes de studerende. Ukendskabet til regler for ophavsret og omgang med personfølsomt materiale ville således næppe være så udtalt, som undersøgelsen efterlader et indtryk af, hvis disse emner blev dækket grundigt i metodeundervisningen på alle fag.

Dette bringer os til spørgsmålet om undervisernes rolle. I interviewene fremgår det af mange udsagn, at relativt få vejledere synes at stille konkrete krav til IT-færdigheder. Nogle benytter Moodle, Mahara eller BSCW og forventer, at de studerende også gør det. Andre har fundet, at Facebook kan være et redskab til at skabe sammenhold og kontakt på et fag. Men der er ikke i undersøgelsen et eneste eksempel på, at vejledere gør studerende opmærksomme på væsentlige akademiske redskaber såsom informationssøgnings-, dataindsamlings- eller analyseprogrammer.

Indledningsvis citerede vi en nyere amerikansk undersøgelse, som hævder, at det akademiske liv fortsat er relativt uberørt af den digitale revolution, og at forskere har tendens til at betragte teknologien som uvæsentlig for deres eget arbejde (Ayers, 2013). Vi henviste også til en undersøgelse fra Københavns Universitet af forskeres informationskompetencer, som kan understøtte en formodning om, at bestemt ikke alle forskere er i stand til at udnytte nye informationssøgningsværktøjer på en effektiv måde (Fisker, Korsgaard \& Hansen, 2014). 
Nærværende undersøgelse har ikke beskæftiget sig med RUC-undervisernes akademiske IT-kompetencer. Men ud fra de studerendes generelle akademiske IT-kompetenceniveau og de studerendes udsagn om undervisernes brug af IT er det indlysende, at det videre arbejde med akademisk IT-skoling bør inddrage ikke blot en kortlægning af undervisernes akademiske IT-kompetencer, men også bredere den akademiske praksis og de faktorer som motiverer/kan motivere til udvikling af praksis.

Udvikling af praksis blandt studerende såvel som undervisere må på et overordnet plan anskues ud fra forandringerne i vilkårene for akademisk arbejde. Gennem de seneste 30-40 år er kompleksiteten af disse blevet voldsomt forøget. Ikke blot er mængden af videnskabelig litteratur vokset nærmest eksplosivt. Det er tilgængeligheden af den også. Mens man tidligere var nogenlunde dækket ind gennem søgning på universitets- og nationalbibliotek, har man i dag alverdens biblioteker til rådighed, plus mængder af information på internettet. For overhovedet at kunne fremfinde, filtrere og vurdere faglitteratur på en meningsfuld måde, er der behov for såvel strategier som specialværktøjer. Og netop hvad disse angår, har vi oplevet den disintermediering, som er et kendetegn ved udbredelse af IT: Der findes adskillige avancerede og dermed også relativt komplicerede værktøjer, men det er i dag op til den enkelte selv at anvende dem, hvor man måske tidligere kunne forlade sig på en bibliotekar.

Når det gælder indsamling og analyse af information samt videnskabelig kommunikation gør noget lignende sig gældende. Værktøjerne er til rådighed, endda i en mangfoldighed, som gør det vanskeligt at vælge det rette. Men det er forskeren eller den studerende selv, som skal vurdere værktøjet og finde meningsfuld anvendelse for det. Hverken forskere eller studerende er blinde for denne udvikling, og det vil være overdrevet og forenklende at hævde, at de teknologiske muligheder er løbet fra den almindelige forskningspraksis. Men der er så betydelige anstrengelser forbundet med grundigt at sætte sig ind teknologien og lære at udnytte den optimalt, at det kan være svært at få øje på fordelene.

\section{Højnelse af niveauet?}

Begrebet "digital dannelse" har været brugt i folkeskolen i årevis (Undervisningsministeriet, 2010), Medierådet for Børn og Unge har beskæftiget sig indgående med emnet (Bundsgaard, Pettersson \& Puck, 2014) og senest har gymnasierne barslet med en 7-punktplan for digital dannelse i gymnasiet, hvori bl.a. indgår klare krav til informationskompetencer (www.danskegymnasier.dk/digitalt-gymnasium). Der er således grund til at forvente, at kommende årgange af studerende vil møde op på de videregående uddannelser bedre rustet til at arbejde systematisk og effektivt med akademiske informationssøgnings- og analyseværktøjer. Eller 
i det mindste, at de vil være motiveret til lære at udnytte fagrelevante ITværktøjer i deres uddannelse.

Det er imidlertid ikke tilstrækkeligt at sætte sig til at vente på, at forholdene bliver anderledes. Nærværende undersøgelse har karakter af en kortlægning af bestemte forhold, og det falder uden for dens rammer at foreslå detaljerede tiltag og retningslinjer for udvikling. Men på et generelt plan kan det uden problemer konstateres, at der er behov for at styrke akademisk Information literacy og Media literacy gennem såvel metode- som biblioteksundervisningen og få den placeret, sådan at den er vedkommende og nyttig i forhold til de studerendes projektarbejde. Et krav om at projektrapporter skal dokumentere, hvordan litteraturen er blevet indsamlet og vurderet, som det allerede kendes fra på visse fag på fx Aalborg Universitet og Det Informationsvidenskabelige Akademi, ville givet også øge opmærksomheden på betydningen af informationskompetencer. For bibliotekets vedkommende vil man være nødt til at arbejde endnu hårdere for at synliggøre de mange forskellige fagspecifikke elektroniske ressourcer, som man har købt adgang til og vurderet, at de studerende har gavn af at benytte undervejs i studierne.

Der er som nævnt grund til at tro, at undervisernes informationsadfærd og valg af IT-værktøjer har betydning for de studerendes måde at agere på. Det vil derfor ligge i naturlig forlængelse af nærværende undersøgelse at studere og også at hjælpe med at udvikle informationsadfærden og evnen til at vurdere og vælge IT-værktøjer blandt det videnskabelige personale på RUC.

Endelig, og i forlængelse af ovenstående, vil det være påkrævet at opkvalificere underviserne, sådan at de kan tage ansvar for at vejlede de studerende inden for akademiske IT-kompetencer på samme naturlige måde, som de vejleder inden for deres fagområde. Forhåbentlig vil IT på længere sigt blive anvendt som et læringsunderstøttende redskab og ikke, som nu, til primært at administrere gruppearbejdet. På sigt vil efteruddannelse være helt nødvendig, blot for at underviserne kan hamle op med de kommende årgange af mere IT-kyndige, nye studerende. Hvordan det skal foregå, er spørgsmål både om politik og ressourcer.

\section{Tak til}

Tak til Mikkel Hvidtfelt Andersen, som inden sit jobskifte i sommeren 2015 var med til at tilrettelægge og udføre spørgeskemaundersøgelsen og som efterfølgende har været en værdifuld diskussionspartner. Ligeledes tak til Michael Pedersen, som har deltaget i planlægningen af spørgeskemaundersøgelse og interviews og desuden har fungeret som med-interviewer og diskussionspartner. Tak til Thorkild Jensen (DEiC) samt Stine Ellefsen, Mads Sinkjær Kjærgaard og Mike Rindom (RUC) for statistik over brug af 
systemer. Og, sidst men ikke mindst, tak til de mange RUC-studerende som på forskellig vis har bidraget til undersøgelsen.

\section{Litteratur}

Andersen, A. S., \& Heilesen, S. B. (Eds.). (2015). The Roskilde Model: Problem-Oriented Learning and Project work. Chaim, Heidelberg, New York, Dordrecht, London: Springer.

Andersen, H. L., \& Heilesen, S. B. (2013). IKT i kvalitetsudviklingen af højere uddannelser - et dansk eksempel. In Y. Nordkvelle, T. Fossland \& G. Netteland (Eds.), Kvalitet i fleksibel høyere utdanning - nordiske perspektiver (pp. 139-153). Oslo: Akademika forlag.

Andersen, M. H. (2015). Draft. ITU Learning technology survey 2015. Copenhagen.

Ayers, E. L. (2013). Does Digital Scholarship Have a Future? Educause Review Online, 24-34. Retrieved November 26, 2015, from http://net.educause.edu/ir/library/pdf/ERM1343.pdf.

Bundsgaard, J., Pettersson, M., \& Puck, M. R. (2014). Digitale kompetencer. It i danske skoler $i$ et internationalt perspektiv. Aarhus: Aarhus Universitetsforlag.

Fisker, A. B., Korsgaard, M., \& Hansen, U. M. (2014). Rapport: Forskeres informationsadfærd (pp. 34). København: Det Samfundsvidenskabelige Fakultetsbibliotek. Det Kongelige Bibliotek.

Gallardo-echenique, E. E., Marqués-molías, L., Bullen, M., \& Strijbos, J-willem. (2015). Let's Talk about Digital Learners in the Digital Era. The International Review of Research in Open and Distributed Learning, 16(3), 156-187.

Jensen, H. P. (2015, 16. oktober). Studerende skal lære at studere, Kronik, Berlingske.

Lai, K.-W., \& Hong, K.-S. (2015). Technology use and learning characteristics of students in higher education: Do generational differences exist? British Journal of Educational Technology, 46(4), 725-738. Retrieved November 26, 2015, from http://doi.wiley.com/10.1111/bjet.12161.

Littlejohn, A, Beetham, H., \& McGill, L. (2012). Learning at the digital frontier: a review of digital literacies in theory and practice. Journal of Computer Assisted Learning, 28(6), 547-556. Retrieved November 26, 2015, from http://doi.wiley.com/10.1111/j.1365-2729.2011.00474.x.

Smith, E.E. (2012). The Digital Native Debate in Higher Education: A Comparative Analysis of Recent Literature. Canadian Journal of Learning and Technology, 38(3).

Spengler, S. (2015). Educators' Perceptions of a 21st Century Digital Literacy Framework. Ann Arbor, MI: ProQuest. 
Thanos, C. (2014). The Future of Digital Scholarship. Procedia Computer Science, 38, 22-27. Retrieved November 26, 2015, from http:// www.sciencedirect.com/science/article/pii/S1877050914013659.

Undervisningsministeriet. (2010). Fælles Mål 2009. It- og mediekompetencer i folkeskolen (Faghæfte 48). København: Undervisningsministeriet. 